\title{
TEACHING STATISTICS THROUGH PROJECTS
}

\author{
Mariana Busatta and Marcos N. Magalhães \\ Universidade de São Paulo, Brazil \\ marianar@ime.usp.br
}

\section{INTRODUCTION}

The goal of education highlighted by several Brazilian official documents is to develop students' critical thinking and acting as well as their autonomy. Teaching statistics through projects contributes to these goals, once it involves analysis and decision making.

\section{PROPOSAL FOR TEACHING-LEARNING}

Our proposal, based on projects and complementary activities, seek to develop the issues mentioned by Gal (2002) in order to develop statistical literacy. That is, the ability to read graphs and tables, statistical, mathematical and research context knowledge, as well as the power to develop critical questions from the readings.

About projects, it is important to pay attention on goals. For Machado (2004), the aims of a project should being open to the new and to the results achieved. It is important the new information production.

Complementary activities are based on discussions and research. According to Freire (1996), dialogue with the students is essential for learning. In this direction, it is necessary to consider their previous knowledge, in order to improve them. For the development of students' prior knowledge, Ninin (2008) points out the great importance of research conduction closely monitored by the educator and the use of technological resources (videos, computers, etc.).

In this context, we produced a proposal to be used with students of the last year of high school. The statistical concepts planned for this step are: graphics; measures of central tendency; measures of dispersion; and sampling elements (São Paulo, 2008). The proposal seeks to provide students experience with statistical analysis: studying the situation of interest as well as obtaining and analyzing information. The study of statistical concepts occurs simultaneously with students' research development. Developing a statistical project will allow students' appropriation of statistical concepts, in order to realize its importance and applicability, without focusing only on mechanical procedures.

\section{FINAL COMMENTS}

At the end of 2014, a pilot application of this proposal was made to develop some of the activities. At the time of this text writing, the proposal is being applied and should be completed in April 2015.

During this pilot application, one could notice a greater involvement of students in class during their projects development. Furthermore, it was evident the contribution of the discussions, which indicated advances in students' conceptions, mainly on statistics aims, mean and dispersion measures. A recurrent idea among students is that the statistical results are uncertain, indicating that students have difficulties with the probabilistic ideas involved in the statistical process.

\section{REFERENCES}

Freire, P. (1996) Pedagogia da autonomia: saberes necessários à prática educativa. São Paulo: Paz e terra.

Gal, I. (2002) Adult's Statistical Literacy: meanings, components, responsibilities. International Statistical Review, v. 70, n. 1, p. 1-25.

Machado, N.J.(2004) Educação: projetos e valores. São Paulo: Escrituras Editora.

Ninin, M.O.G. (2008) Pesquisa na escola: que espaço é esse? O do conteúdo ou o do pensamento crítico? In. Educação em Revista. Belo Horizonte, nº48, p.17-35.

São Paulo (2008), Secretaria de Estado da Educação. Proposta Curricular do Estado de São Paulo: Matemática. São Paulo. 